\title{
Vegetation Maps at the Passage of the Taylor Grazing Act (1934): A Baseline to Evaluate Rangeland Change After a Regime Shift
}

\section{By Rhonda Skaggs, Zach Edwards, Brandon T. Bestelmeyer, John B. Wright, Jeb Williamson, and Phil Smith}

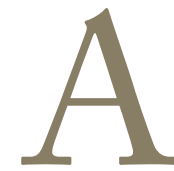

project to digitize historic range survey maps for southern New Mexico was undertaken by a team from the US Bureau of Land Management (BLM) Las Cruces District office, New Mexico State University, and the US Department of AgricultureAgricultural Research Service Jornada Experimental Range. These maps originated with the passage of the Taylor Grazing Act in 1934 and were prepared in the mid-1930s. The Taylor Grazing Act represents a regime shift ${ }^{1}$ in the management of rangelands of the western United States that addressed the perception of widespread degradation with an unprecedented policy response. Prior to our efforts, data in the range survey maps were not readily accessible to researchers and land managers conducting long-term studies of rangeland conditions. Such data have proven of great value in long-term research. For example, research stations including the Jornada Experimental Range and the National Science Foundation's Long Term Ecological Research network engage in research to understand the long-term, large-scale ecosystem changes associated with biological, physical, and socioeconomic forces. Information about ecosystem conditions before and after major historical events or policy changes is an important tool for explaining past changes and predicting future ones. The Taylor Grazing Act was one such event; it initiated active federal management of public-domain rangelands and established property rights for what were previously open range grazing conditions. Thus, the passage of the Taylor Act constitutes a critical driver in the development of western US rangelands, the consequences of which are poorly understood in longterm research in southern New Mexico and elsewhere. Data from the original Taylor Act range-survey maps should be regarded as a legacy resource to be preserved and one that can provide a valuable baseline of information to understand how rangelands have evolved over the last seven decades in response to a policy shift. ${ }^{2}$ Here, we describe the process by which we have made this data resource available to the research community in southern New Mexico and how we are using it. Our hope is that this example inspires and facilitates similar efforts elsewhere.

\section{Background}

In the early 1930s, the rangelands of the western United States were in extremely degraded condition. Almost 150 million acres of land remained "vacant, unappropriated, and unreserved" 3 and part of the public domain in 11 contiguous western states. Homesteading in the West had been underway since the 1860 s, with various adjustments made to federal homestead laws in recognition of the limited agricultural productivity of much of the region. However, millions of acres in the West had not been successfully homesteaded because they were too dry, too high in altitude, and suited only to livestock grazing. Some properties had been claimed and abandoned but homesteading was never attempted on much of the land. Domestic livestock were introduced into the region approximately 450 years ago, and by the mid1880 s, the cattle population was estimated to have reached 35-40 million animals. ${ }^{4}$ Bad weather and collapsing markets then took their toll on the cattle industry, and numbers declined in the late 1800s. Drought, overgrazing, and competition for forage resources among cattle producers, as well as between sheepherders and cattlemen, were damaging the 
industry and the land. With virtually no regulation of the public domain, conflicts over use of the western rangelands were not uncommon. In the absence of land laws, ranchers attempted to secure grazing lands through intimidation, illegal fencing, and control of water sources. ${ }^{5}$ These lands were a huge commons, subject to private capture by legal and extralegal means. They were also vulnerable to steady deterioration due to unsustainable use. The federal government began to assert its control over grazing on unregulated forest lands in the late 1890s with the creation of forest reserves. With the establishment of the Forest Service in 1905, procedures for administration of grazing were developed and grazing permits on lands under that agency's control were issued. However, millions of acres of western lands remained unregulated and by the late 1920s the debate had intensified regarding the future of the remaining public domain grazing lands throughout the West. The Hoover administration favored turning over the lands to the states in which they were located. Other observers, including many conservationists, did not want to allow the lands to be removed from federal control. Ultimately, the debate was settled with the passage of the Taylor Grazing Act in June 1934, one of several New Deal legislative efforts passed during a period of extreme economic and climatological crises.

The Taylor Grazing Act effectively ended homesteading in the 11 western states and asserted full federal control over the remaining public domain lands. The objectives of the Taylor Act were to prevent overgrazing and soil deterioration on the public grazing lands, establish orderly use and improvement of the lands, and stabilize the livestock industry dependent on the lands. The Taylor Act was passed at a time when both the Great Depression and extreme drought were contributing to the urgent need to regulate public domain lands. Implementation of the Taylor Act was to involve establishment of grazing districts throughout the West. The first administrator of what became the Grazing Service, Farrington Carpenter, was appointed by Secretary of the Interior Harold Ickes in 1934, and later that year, Carpenter began the process of federal administration of the West's public grazing lands. Carpenter was given very limited resources with which to carry out the mandate of the Taylor Act. There were no direct appropriations for funding the Act, and Carpenter was loaned 17 employees from the US Geological Survey, the Federal Bureau of Investigation, and other federal agencies. ${ }^{6,7}$ In a 1962 speech, Carpenter described how after he was given the job of implementing the Taylor Act, he went to the General Land Office in search of maps that would tell him where the public lands were, only to find out that there were no maps of the public domain lands. ${ }^{6,8}$ According to Carpenter, the locations of public domain lands were identified through a process of elimination using township tract maps obtained from local district land offices which had privately held land parcels identified.

Carpenter then began a process of stakeholder involvement in implementing the Taylor Act. Cattle and sheep producers using the public domain lands participated in meetings where they were asked to draw grazing district boundaries. According to Carpenter, "They knew their barriers, they knew where the public lands were and it was from their initial work at the official meeting that the grazing districts exist today." 6 This process began the formal division of grazing districts into subareas called units, and the division of units into allotments, for which permits were issued for livestock grazing. The Taylor Grazing Act adjudication process began in 1934 but was not completed until the mid-1960s due to the limited number of Grazing Service employees, World War II, and political controversies.9

Six grazing districts were delineated in New Mexico by summer 1936 and, at that time, the work of developing public grazing land maps for use in the adjudication process began. The maps were to show the intermingled private and state-owned lands, vegetation characteristics, topography, accessibility for grazing, fences, and waters suitable for livestock use. ${ }^{10}$ The New Deal's Civilian Conservation Corps (CCC) program had begun to enroll young, unemployed men to work on conservation projects throughout the United States in 1933. The newly formed Division of Grazing was given no funds for recruiting draftsmen or range surveyors, and thus made arrangements with the $\mathrm{CCC}$ to recruit and train range survey crews from several CCC camps in New Mexico. ${ }^{10}$ The first, trial-run range survey crew completed their work in south-central New Mexico by September 1936, and members of that original crew then formed their own eight-man crews by selecting more men from the New Mexico CCC camps. Two-month training sessions were carried out in CCC camps, and after the training, each crew was assigned to other New Mexico grazing districts (Fig. 1).

With the help of the CCC program and US Army officials, each range survey crew was supplied with a 1-ton truck, a trailer equipped to serve as a kitchen and shower, tents with floors for sleeping quarters and an office, and an eight-passenger station wagon. ${ }^{11}$ According to the memoirs of R. D. Nielson, the tools supplied to the range surveyors included a Brunton compass, a Jacob staff, an Aneroid barometer, a plane table, clipboards, pencils, rulers, small hand mirrors for signaling adjacent surveyors, and first aid kits. ${ }^{10,11}$

The range survey crews worked from township to township. Crew members traversed section lines through townships on foot, north and south or east and west, and recorded the necessary information on a blank township plot. ${ }^{10} \mathrm{~A}$ survey crew foreman would pick up the range surveyors and return them to camp at the end of their 6-mile hikes. The crew foremen delivered the information gathered by the individual range surveyors to the crew recorder, who then transferred information to a compilation map, which was later taken to Albuquerque where it was recorded onto large maps or plats. The New Mexico crews were later moved to grazing districts in Arizona, with range surveying completed in the two states by autumn $1940 .{ }^{10}$ 


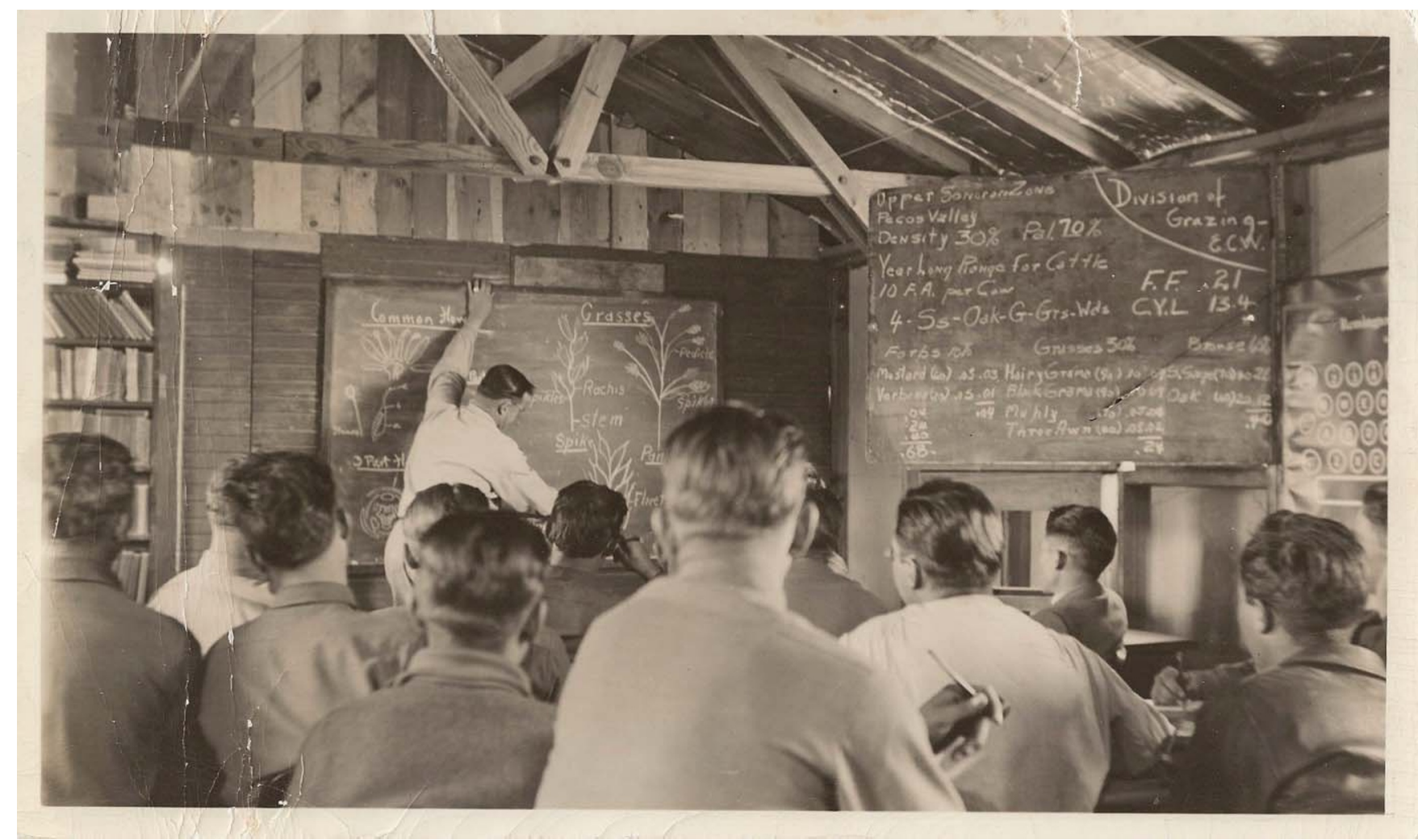

Figure 1. Division of Grazing-Emergency Conservation Work range survey crew training session, Carrizozo, New Mexico, 1936-1937. Photo by R. D. Nielson. Photo courtesy of Public Lands Foundation.

Under the Taylor Act, permits specifying what types of livestock could be grazed, total number of animal-unitmonths of grazing allowed, and the season within which grazing was allowed were initially issued on an annual basis. However, as soon as the carrying capacity of the land was established, permits could then be issued for 10-year terms. ${ }^{12}$ The original 1930s range surveys were indispensable in the early adjudication of grazing applications, including the establishment of grazing allotment boundaries and assignment of grazing allotments, and were used in appeals, judicial hearings, and conflict resolution. ${ }^{10}$

The information recorded by the range surveyors included vegetation types, vegetative composition, and palatability to livestock. They also noted watering facilities, general topography, improvements, and infrastructure (Fig. 2). The range survey foreman who signed the map in Figure 2, Wilbur Gaines, was one of the first range surveyors recruited from among CCC foremen and crews in New Mexico. ${ }^{11}$ The map was drawn for four townships; each 640-acre section of land is labeled with a forage utilization factor, which ranges from U-85 to U-150. The locations of several wells, homesites, ranch headquarters, camps, Southern Pacific Railroad tracks, fences, contour lines, a natural gas pipeline, primitive roads and trails, and numerous irregular polygons are shown. The polygons are of particular interest because of the vegetation codes recorded for them. The vegetation codes shown on the maps are the first systematic documentation of forage resources on the public domain lands that are currently managed by the BLM.

Many of the public domain grazing lands in southern New Mexico have been subject to broad-scale conversion of perennial grasslands to dominance by xerophytic woody

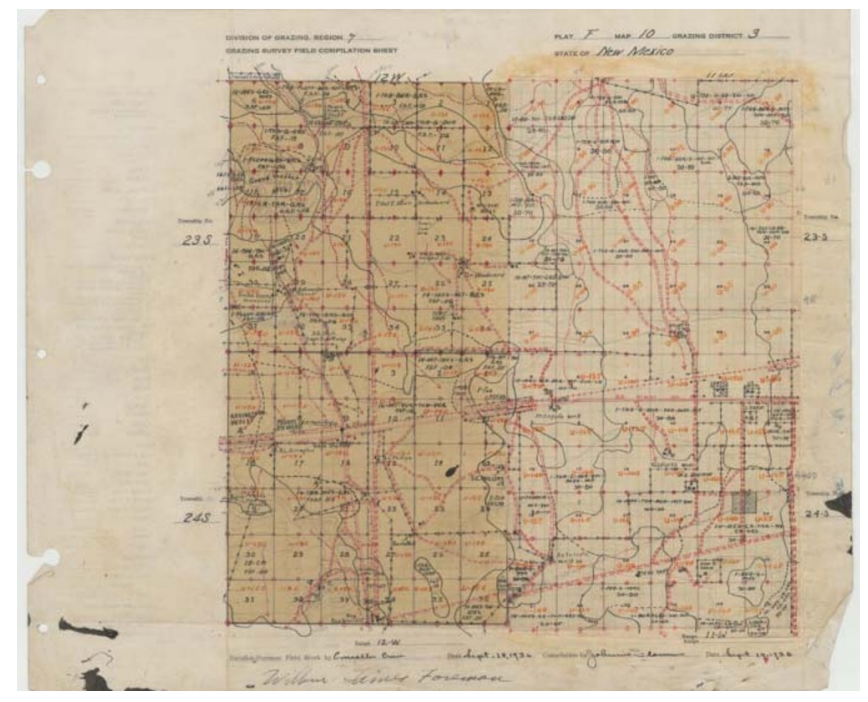

Figure 2. Scanned image of a range survey map for southwestern New Mexico Grazing District No. 3, 1936. 
plants and the associated loss of soils and biological resources. What were once grass and shrub mosaic landscapes dominated by black grama (Bouteloua eriopoda) or tobosa (Pleuraphis mutica) are now dominated by woody species such as honey mesquite (Prosopis glandulosa) and creosote bush (Larrea tridentata). Given the long history of domestic livestock in the region, expansive vegetation changes clearly began long before implementation of the Taylor Grazing Act; however, the range survey maps prepared in the 1930s are the first broad-scale documentation of the region's vegetative cover.

\section{Preserving Data From 1930s Range Survey Maps}

Student and professional employees of New Mexico State University's Spatial Applications Research Center (SpARC) worked with local BLM staff to scan the 1930s-era maps using a large-format scanner located at the BLM offices. The maps were scanned at a high resolution and saved as tag image file format (raster) files. The newly created digital adjudication maps were moved into ArcMAP ${ }^{\odot}$ for georeferencing (e.g., defining the existence of a dataset in physical space). The maps were georeferenced by snapping control points (known locations) on the maps themselves to vertexes in the Public Land Survey System (PLSS) sections vector feature class. The georeferenced raster adjudication maps were then compiled into a raster catalog for efficiency and organizational purposes. ${ }^{13}$

The newly created raster catalog was brought into $\operatorname{ArcMAP}^{\odot}$ along with the PLSS sections feature class to enter in the forage utilization factor values. The utilization values were written on the adjudication maps by section and SpARC staff entered these values in the PLSS sections feature class by section in a field called "U_Code." There were many sections in the historical maps where no $U$ values were present, and accordingly these remained null in the sections dataset.

A polygon feature class was created to contain the vegetation data to be digitized from the range survey maps. The empty vegetation feature class was brought into ArcMAP $^{\odot}$ with the range survey maps raster catalog. SpARC staff digitized the hand-drawn vegetation areas at a fairly large map scale (1:3,000-1:5,000). After each vegetation polygon was created, vegetation attributes were entered in the attribute table, which were defined as "Veg_number, veg, veg1, veg2, veg3, veg4, and Veg_Range.” An example of this data for one polygon at the bottom right of Figure 2 is as follows: $1-B U R-G-M E S$ 30-80. Using these data, this polygon is primarily grassland $(=1)$, dominated by burrograss (Scleropogon brevifolius) and "grama" grass (any of several Bouteloua species), with the presence of mesquite (Prosopis glandulosa). Density of the vegetation was rated $30 \%$ and palatability was rated at $80 \%$.

The photograph of range survey crew training (Fig. 1) shows vegetation coding of $4-\mathrm{Ss}-\mathrm{Oak}-\mathrm{G}-\mathrm{Grs}-\mathrm{Wds}$ for the Pecos Valley on the blackboard. Notes for this photograph indicate it was taken in "1936-37". Instructions for Range Surveys (formulated by the Inter-Agency Range Survey Committee and adopted April 24, 1937) were published after the New Mexico range survey work was already underway. ${ }^{14}$ This document includes the instruction that "Species symbols will consist of the first letter of the Latin generic name, followed by the first two letters of the specific name." The New Mexico range surveying apparently was conducted before the vegetation naming convention had been established; thus common names were used for vegetation coding and numerous inconsistencies in the newly digitized data have been found as a result. The Instructions for Range Surveys document and other documents ${ }^{15,16}$ have provided valuable insight into interpretation of the New Mexico range survey maps; however, documentation specific to the New Mexico maps has not been located as of this writing.

Because the historic range survey maps are so old and were created by several different surveyors or cartographers, SpARC staff encountered numerous readability and legibility issues. Furthermore, many of the plats have multiple linear features which made it difficult to exactly determine the extent of the vegetation polygons and their corresponding codes. Due to these issues, coding of vegetation attributes was the most important and most time-consuming portion of the map digitization process.

After all the map digitizing was completed, topology was built and errors were corrected. Several problems with topology corrections were encountered due to a combination of procedural and user error. SpARC staff made the topology corrections through an iterative process and developed a protocol for the corrections. SpARC staff concluded that the best way to avoid topology errors when digitizing a contiguous polygon dataset is to simultaneously use the "trace" tool and the "auto-complete" polygon function, and that users need to verify they are snapping to the correct dataset and using the appropriate snapping tolerance when editing the data. These procedures reduce the numbers of slivers, gaps, and overlaps that are inevitable when creating a large contiguous-vegetation land cover. Following corrections, all the range survey map data were exported or copied into a file geodatabase and given appropriate names, and final metadata edits were applied to all the project data. ${ }^{17}$ Significant effort has been spent on correctly classifying vegetation metadata from the various common names recorded on the maps.

\section{Using Vegetative Cover Data From the 1930s Range Survey Maps}

The 1930s cover data provide a valuable resource for historical studies of vegetation change in the region. The maps provide a snapshot of vegetative conditions at a point in time when significant public land regulatory change occurred. Smallscale, isolated rangeland vegetation studies were conducted 


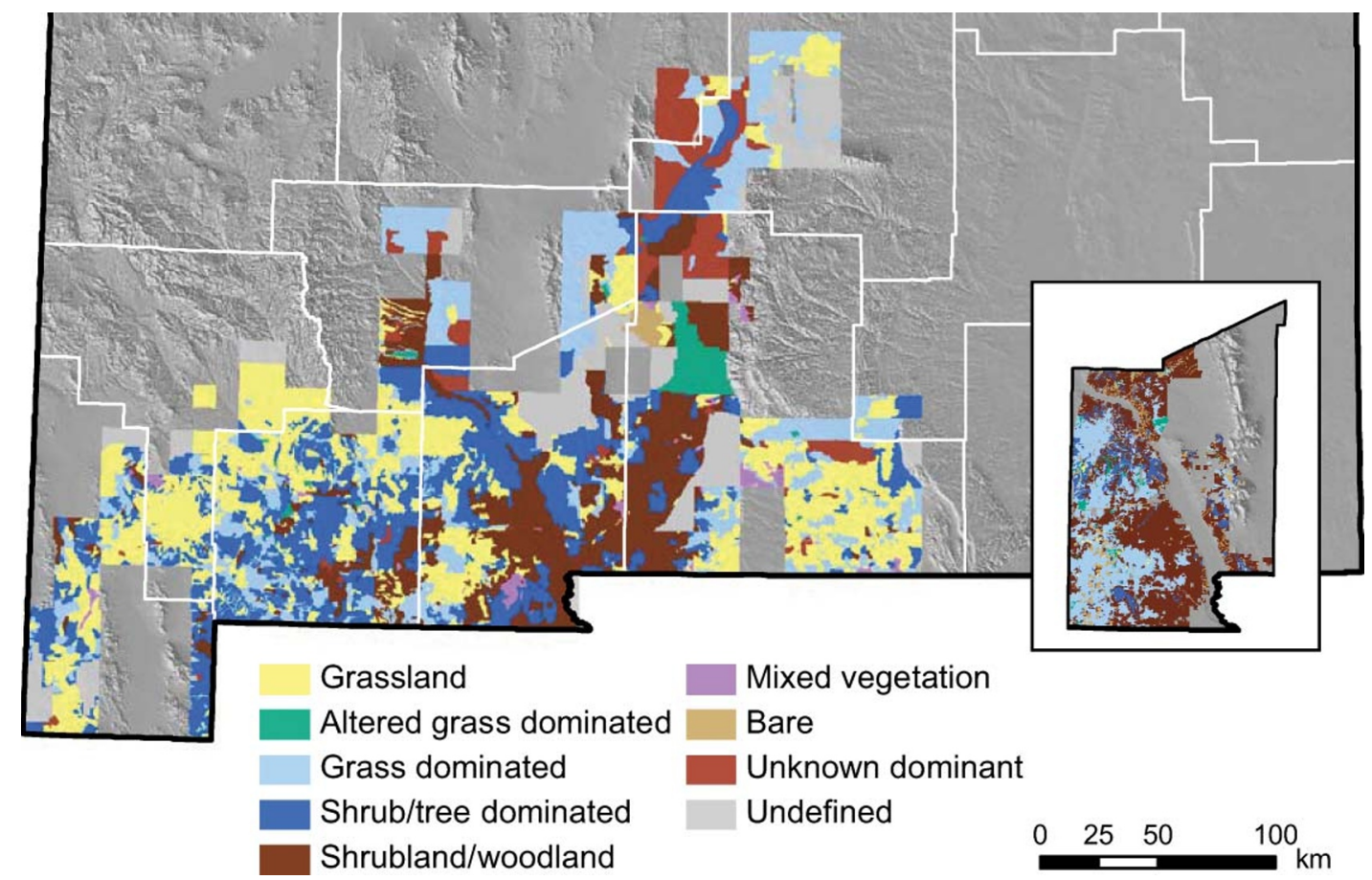

Figure 3. Reclassified 1930s range survey map of southern New Mexico. Plant species recorded for each map polygon were used to assign polygons to a modern generalized state class. This procedure has facilitated spatial comparisons of historic data with modern ecological state maps, such as that shown in the inset for Doña Ana County.

in selected areas of the West in the decades preceding the Taylor Act (e.g., on New Mexico's Jornada Experimental Range and Arizona's Santa Rita Experimental Range); however, the geographic coverage of the 1930s range survey data is not matched by any other data source in either the pre- or post-Taylor Act eras. General Land Office Survey data, for example, often do not provide sufficient details on species composition. ${ }^{18,19}$ Thus, the 1930s range survey data are essential to the development of state-and-transition models used by land management agencies. ${ }^{20}$ These models describe vegetation dynamics for particular land areas, and are usually based on data from a small number of experimental sites for which longitudinal data are available. The regime shift resulting from the Taylor Act was regional in its impact, matching the regional coverage of the 1930s vegetation data. Because the 1930s data are georeferenced they can be used in modeling and analyses at the scale of landscapes. Although the 1930s data do not necessarily reflect reference conditions with regard to rangeland health or ecological potential, they provide a picture of historical vegetation states from which current states have evolved. The 1930s data can help us quantify the impact of the Taylor Grazing Act, alongside subsequent changes in policy and land use practices, on vegetation states.

To this end, the range survey map data are being used in a geographic information system (GIS) that compares 1930s vegetation with more recent vegetation mapping data to evaluate change in broad vegetation attributes, such as grassland to shrub savanna or shrubland within a grazing allotment and across multiple allotments. ${ }^{20,21}$ The maps will also be referenced to other georeferenced historical data, such as aerial photographs and General Land Office Surveys. The availability of spatial information on plant community composition during the 1930s period provides useful data for interpreting variation in the rapidity of transitions (as well as stasis) in a period following an important policy shift. Such analyses can contribute to our understanding of the forces governing recent transitions in arid rangelands.

Figure 3 illustrates one way the 1930s vegetation cover data have been used to examine changes in rangeland condition through time. Plant species codes recorded on the historic survey maps were used to translate digitized maps into a modern generalized ecological state classification. ${ }^{20}$ This allowed the historic data to be compared to present-day ecological state maps of southern New Mexico generated through aerial photo interpretation. An algorithm was developed to assign each range survey polygon to one of nine classes based on the species listed for that polygon (Table 1) and reclassification of digital data was implemented in ArcGIS ${ }^{\odot}$ using a custom script. This process required a host of assumptions about how the 1930s range surveys were conducted. For example, the species codes recorded for each polygon were assumed to be the dominant species within that area, the more dominant species were assumed to be listed first, and the protocol for listing species was assumed to be regionally consistent. These three assumptions appear to be reasonable given range survey methods of the time. ${ }^{16}$ Assumptions about map attributes, 
Table 1. General description of the rule sets used to reclassify the 1930 s range survey maps and modern ecological state maps to a compatible format. Plant species recorded on historic maps were assumed to be the dominant species, listed in the order of their dominance. Ecological state maps were reclassified based on the dominant state within each polygon

\begin{tabular}{|c|c|c|}
\hline Reclassification & 1930 s range survey maps & 2010 state maps \\
\hline Grassland & $\begin{array}{l}\text { Historically dominant grass species listed; no } \\
\text { invasive shrubs listed. }\end{array}$ & Grassland \\
\hline Grass-dominated & $\begin{array}{l}\text { Both historically dominant grass species and } \\
\text { invasive shrub species listed, but historically } \\
\text { dominant grass species listed first. }\end{array}$ & Shrub/tree savanna or shrub/tree invaded \\
\hline $\begin{array}{l}\text { Altered grass- } \\
\text { dominated }\end{array}$ & $\begin{array}{l}\text { Grass species listed first, but not historically } \\
\text { dominant species. If invasive shrub species } \\
\text { also listed, it appears after the grass species. }\end{array}$ & Altered grassland \\
\hline Shrub/tree-dominated & $\begin{array}{c}\text { Both historically dominant grass species and } \\
\text { invasive shrub species listed, but invasive } \\
\text { shrub species listed first. }\end{array}$ & Shrub/tree-dominated \\
\hline Shrubland/woodland & $\begin{array}{l}\text { Invasive shrub species listed; no historically } \\
\text { dominant grass species listed. If non-histori- } \\
\text { cally dominant grass species listed, it appears } \\
\text { after the shrub species. }\end{array}$ & Expansion shrubland/woodland \\
\hline Bare & $\begin{array}{l}\text { Vegetation no. } 8 \text { and no dominant species } \\
\text { listed. }\end{array}$ & Bare/annuals \\
\hline Mixed vegetation & $\begin{array}{l}\text { Assemblage of shrubs and/or forbs not repre- } \\
\text { senting one of the above classes. }\end{array}$ & N/A \\
\hline Unknown dominant & $\begin{array}{l}\text { The code listed first could not be translated } \\
\text { to a modern species code. }\end{array}$ & N/A \\
\hline Undefined & $\begin{array}{l}\text { Areas are delineated on the map but not sur- } \\
\text { veyed. }\end{array}$ & N/A \\
\hline
\end{tabular}

together with differences in scale and methods between the historic and modern maps somewhat limit what can be interpreted about ecological change using these two data sources. Despite inevitable inaccuracies, such manipulations of the 1930s range survey data are likely to offer insight into historic rangeland conditions at a scale unobtainable from other sources.

\section{Conclusions}

The 1930s range survey maps are a valuable data resource for the rangeland science community. The maps help document relatively recent changes in vegetation at unprecedented spatial scales. The timing of the record is valuable as well, occurring at the time of a critical shift in rangeland policy and practice in federal lands of the United States. Where they have been preserved, such maps should be available for public lands throughout the western United States These maps should be treated as irreplaceable historical documents and be archived and curated appropriately. The methods we described could be used throughout the western United States to make the data contained in these maps available for modern GIS-based analyses of vegetation change. Combined with maps of present vegetation, such analyses could produce a vastly improved understanding of the spatial dimensions of long-term change in federal rangelands.

\section{Acknowledgments}

Special thanks to Glendon Collins and John W. Riley, both with BLM (retired) and Public Lands Foundation.

\section{References}

1. Folke, C., S. Carpenter, B. Walker, M. Scheffer, T. Elmevist, L. Gunderson, and C. S. Holling. 2004. Regime shifts, resilience, and biodiversity in ecosystem management. Annual Review of Ecology, Evolution and Systematics 35:557-581.

2. Foster, D. R., F. Swanson, J. Aber, I. Burke, N. Brokaw, D. Tilman, and A. Knapp. 2003. The importance of land-use and its legacies to ecology and environmental management. BioScience 53:77-88.

3. Taylor Grazing Act. 1934 (28 June); 43 U.S. Code $§ \S 315-$ 316o, as amended 1936, 1938, 1939, 1942, 1947, 1948, 1954, and 1976. 
4. Holechek, J. L., R. D. Pieper, and C. H. Herbel. 1989. Range management principles and practices. Englewood Cliffs, NJ, USA: Prentice Hall. 501 p.

5. Merrill, K. R. 2002. Public lands and political meaning. Berkeley, CA, USA: University of California Press. 274 p.

6. Carpenter, F. R. 1981. Establishing management under the Taylor Grazing Act. Rangelands 3(3):105-115.

7. Carpenter, F. R. 1984. Confessions of a maverick: an autobiography. Denver, CO, USA: State Historical Society of Colorado. 222 p.

8. Chambers, G. 1984. Ferry Carpenter. In: The Taylor Grazing Act 1934-1984, 50 years of progress. Boise, ID, USA: U.S. Bureau of Land Management. p. 7-8.

9. Sharp, L. 1984. Overview of the Taylor Grazing Act. In: The Taylor Grazing Act 1934-1984, 50 years of progress. Boise, ID, USA: U.S. Bureau of Land Management. p. 9-10.

10. Nielson, R. D. 1995. Range surveys and resource inventory New Mexico and Arizona 1936-1940. From the papers of R. D. Nielson, held by the Public Lands Foundation Archives, Phoenix, AZ, USA.

11. Nielson, R. D. 2005. Report on how the West was run during the twentieth century. R. D. Nielson.

12. Calef, W. 1960. Private grazing and public lands: studies of the local management of the Taylor Grazing Act. Chicago, IL, USA: University of Chicago Press. 292 p.

13. ESRI [computer program]. 2008. ArcGIS, Version 9.3. Help index, keyword, raster catalog. Redlands, CA, USA: ESRI.

14. Interagency Range Survey Committee. 1937. Instructions for range surveys. As formulated by the Inter-Agency Range Survey Committee and adopted by the Western Range Survey Conference. Washington, DC, USA: Interagency Range Survey Committee. 32 p.

15. Interagency Range Survey Committee. 1939. Approved palatability List. Supplemented by those species common to the Rio Grande Valley, Navajo Reservation, and surrounding vicinity. Washington, DC, USA: Interagency Range Survey Committee. $16 \mathrm{p}$.

16. U.S. Department of Agriculture Agricultural Adjustment Administration, Western Division, 1940. Instructions to field range examiners for making range surveys. Washington, DC, USA: U.S. Department of Agriculture Agricultural Adjustment Administration, Western Division. Report WD-25.16 p.

17. ESRI. 2002. Metadata and GIS. Available at: http://www.esri. com/library/whitepapers/pdfs/metadata-and-gis.pdf. Accessed 5 January 2011.
18. Gibbens, R. P., R. P. McNeely, K. M. Havstad, R. F. Beck, And B. Nolen. 2005. Vegetation changes in the Jornada Basin from 1858-1998. Journal of Arid Environments 61:651-658.

19. Yanoff, S., And E. Muldavin. 2008. Grassland-shrubland transformation and grazing: a century-scale view of a northern Chihuahuan Desert grassland. Journal of Arid Environments 72:1594-1605.

20. Bestelmeyer, B. T., A. J. Tugel, G. L. Peacock, Jr., D. G. Robinett, P. L. Shaver, J. R. Brown, J. E. Herrick, H. Sanchez, and K. M. Havstad. 2009. State-and-transition models for heterogeneous landscapes: a strategy for development and application. Rangeland Ecology Eं Management 62:1-15.

21. Lowry, J. H., Jr., R. D. Ramsey, K. Boykin, D. Bradford, P. Comer, S. Falzarano, W. Kepner, J. Kirby, L. Langs, J. Prior-Magee, G. Manis, L. O’Brien, K. Pohs, W. Rieth, T. Sajwaj, T. S. Schrader, D. Schrupp, K. Schulz, K. A. Thomas, B. Thompson, C. Velasquez, C. Wallace, E. Waller, and B. Wolk. 2007. Mapping meso-scale land cover over very large geographic areas within a collaborative framework: a case study of the Southwest Regional Gap Analysis Project (SWReGAP). Remote Sensing of the Environment 108:59-73.

Authors are Professor, Agricultural Economics and Agricultural Business, New Mexico State University, Las Cruces, NM 88003, USA, rskaggs@nmsu.edu (Skaggs); Geographic Information Systems Coordinator, Spatial Applications and Research Center, Dept of Geography, New Mexico State University, Las Cruces, NM 88003, USA (Edwards); Research Ecologist, USDA-Agricultural Research Service Jornada Experimental Range, New Mexico State University, Las Cruces, NM 88003, USA (Bestelmeyer); Professor, Dept of Geography, New Mexico State University, Las Cruces, NM 88003, USA (Wright); Geographic Information Systems Specialist, New Mexico State University, Las Cruces, NM 88003, USA (Williamson); and US Bureau of Land Management, Las Cruces District Office, Las Cruces, NM 88005, USA (Smith). This work was supported by the New Mexico Agricultural Experiment Station, the USDA-Agricultural Research Service Jornada Experimental Range with funding by the USDA, and the National Science Foundation grant DEB-0618210, as a contribution to the Jornada Long-Term Ecological Research program. 